\title{
An Assessment of the Effect of Micro Credit on Poverty Status of Rural Crop Farmers in Edo State, Nigeria.
}

\author{
* K. O. Ilavbarhe and **P. B. Imoudu \\ *Department of Agricultural Economics and Extension Services, University of Benin, Benin City \\ **Department of Agricultural Economics, Federal University of Technology, Akure
}

\begin{abstract}
The study evaluated the effect of micro credit on poverty status of rural crop farmers in Edo State, using the problem of inadequate capital for the development of the agricultural sector as the main frame of reference. The objective of this study is to determine the effect of micro credit on farm size, output, income and the incidence, intensity and severity of poverty of beneficiaries and compared these with those of non beneficiaries.

Primary and secondary sources of data were used. Primary data were obtained from interview schedule. Three hundred (300) copies of well filled out questionnaire each from beneficiaries and non beneficiaries respectively were analyzed using frequency counts, means, test of differences in mean and poverty indices. Our findings were that the mean farm size was 1.81 hectares for beneficiaries and 1.73 hectares for non beneficiaries. Output of beneficiaries in maize, cassava and yam were higher than those of non beneficiaries. Beneficiaries had higher income from the sale of these produce than the non beneficiaries. $21 \%$ of beneficiaries and $43 \%$ of non beneficiaries were found to be below the poverty line of ninety nine Naira, forty kobo only (N99.40) which is equivalent to sixty six America cents per day. Of the poor beneficiaries, $20 \%$ were categorized as core poor, 1\% hard core poor while 40\% were core poor and 3\% hard core poor among the poor non beneficiaries. The study also revealed that the incidence, intensity and severity of poverty were higher with non beneficiaries than with beneficiaries. It was therefore concluded that access to micro credit alleviates poverty and improves the economic status of beneficiaries.
\end{abstract}

Keywords: assessment, effect, micro credit, poverty status, crop farmers

\section{Introduction:}

There is considerable improvement in the world production of food in the last few years but over 80 million people are still undernourished. This is not because of food deficit and inadequate distribution but because the incomes of the poorest are too low to allow them to procure balanced food in sufficient quantities. Nigerian farmers lack access to productive resources as well as output market. Most of these farmers have small farms, use traditional inputs that are capable of generating only very low savings and low investment. The main assets of these farmers are labour and simple implements. Available technology implies that there is a large and real potential for the development of the agricultural sector. The adoption of these new technologies which comprises of improved biological materials, agrochemicals and farm implements requires the injection of capital from nonfarm sources. A common belief is that capital is the most limiting factor in any productive venture (Coleman, 1999).

Lack of capital is thought to be the primary cause of low labour and land productivity. This low level of production results in low levels of income as all what is produced is consumed. Since there are no surpluses above subsistence level in the form of savings, farmers lack investment capital and are therefore caught up in a web of vicious circle of poverty (Imoudu, 1999).

A working definition from Professor Muhammad Yunus, the Noble Peace Prize winner in 2006 is 'Poverty is that characteristic of being in a state of joblessness, homelessness, lack of adequate capital, facilities and food to earn a decent living and also powerlessness. Poverty exists when one or more persons fail to attain a specified level of well being that is deemed to constitute a reasonable minimum standard of living set by that society (Ravallion, 1992). Imoudu (1998) sees poverty as a condition of living with little or no money required in providing the basic necessities of life such as shelter, food and clothing. Poverty alleviation according to Nikhil (2009) is the act of reducing the scourges of the above conditions of individual or community. According to statistics, about $25 \%$ of the population in developing regions lives below the poverty line (United Nation, 2009). This translates to 1.3 billion people living in poverty, or about $20 \%$ of the global population (The World Bank Group, 2010). Poverty contributes to physical weakness through lack of food. This in turn reduces the labour force available for farm work. For farmers to break away from this vicious circle of poverty there is the need for the injection of outside funds in the form of credit.

Credit is a device for facilitating the temporary transfer of purchasing power from one individual to 
another (Oyatoye, 1981). A lender temporarily forgoes the use of his money or its equivalent in the present by extending credit to a borrower who promises to repay on terms specified in the loan agreement (Ilavbarhe, 2007). At the end of the contract period, the control ceases and the funds revert to the initial owner. Micro credit is the extension of small financial assets to poor people without collateral, to help reduce their financial burden and alleviate poverty. In recent public debates, micro credit has been mentioned as an important instrument for poverty alleviation in developing countries. The attention for micro credit and its role of reducing poverty was further increased when the United Nations declared 2005 to be the international year of micro credit, and when Mohammed Yunus, the founder of the Gramen Bank, received the Nobel Peace prize in 2006, according to the Nobel committee micro credit can help people to break out of poverty (Nobel Committee, 2006). The amount given out as micro credit ranges from one thousand to fifty thousand Naira (N1, 000-N50, 000). It is a way of helping the poor to access the financial market without the required collateral. Efforts at expanding access of the poor to credit have focused largely on channeling credit through micro credit organizations. Micro credit has been proven to have positive effect in reducing poverty in Bangladesh (Hassain and Knight, 2008; Chemin, 2008). Beneficiaries not only obtain financial benefits but also encompass gender empowerment and self actualization (Mamun, et al, 2013). They went further to say that if clients chooses to borrow from micro credit organizations, they are required to attend and participate in capacity building programmes, entrepreneurship, risk management skills, credit discipline, values formation, information of health and family planning are discussed and taught to equip borrowers with proper knowledge. This has led to an almost euphoric attitude among practitioners and policy makers about the potential poverty reducing effects of micro credit. It is unclear whether micro credit can really help to reduce poverty. Scully, (2004) showed that micro credit does not reach the poorest of the poor. It is also very difficult to analyze the effect of micro credit on poverty alleviation. A major problem is how to measure the contribution of micro credit to poverty alleviation among the poor. In this study, we measure the effect of micro credit by comparing recipients of microfinance with a control group that have no access to micro credit. Therefore, some of the questions this study is set to answer are: Does micro credit increase the entitlements of borrowing farmers through increasing their output and income? To what extent have the micro credit schemes helped in enhancing the poverty status of these farmers?

The objective of this study therefore is to assess the effect of micro credit on poverty status of rural crop farmers in Edo State, Nigeria.

\section{Methodology:}

The study was carried out in Edo State, Nigeria. The state has a population of about 2, 159, 842 people which is about 2.4 percent of the total population of Nigeria (NPC, 1994). It has a land mass of $17,920 \mathrm{~km} 2$ with a population density of 121 people per square kilometer. It lies between longitude 0604 and 0643 East and latitude 0544 and 0734 North of the equator. The people are mainly agrarian producing a variety of crops such as yam, cassava, rice, maize, sorghum, plantain, cocoa, coffee, oil palm, rubber, timber, cocoyam and animal husbandry. A small proportion of the populations are engaged in carving, blacksmithing and carpentry.

Data for the study were collected through the use of a well structured questionnaire administered by staff of the Edo State Agricultural Development Programme (ADP). A multi stage sampling procedure was adopted in this study for the selection of respondents. The decision to employ multi stage sampling procedure was premised on the fact that Edo State is divided into three geographical zones. The three zones were purposively selected to give a statewide coverage. Within the Zones, two-third (2/3) of the local government areas (blocks) was randomly selected and two communities (cells) in each of the selected blocks were randomly taken. A systematic random sampling was used to select on the average seventeen (17) beneficiaries and seventeen (17) non beneficiaries of the micro credit schemes from each cell. Four hundred (400) copies of the questionnaire were administered to beneficiaries and non beneficiaries of the micro credit schemes respectively. Structured interview schedule was used for the non literate respondents, while sets of questionnaire were administered on the literate counterparts. Three hundred (300) copies each of well completed questionnaire were retrieved from beneficiaries and non beneficiaries respectively.

\section{Data Analysis}

The data were analyzed using frequency counts, mean, test of differences in mean and poverty indices as developed by Foster, Greener and Thorbecke (1984) and adopted by Uniamikogbo (1999). The formulae are: Test of difference in sample mean ( $z$ test) is

$$
Z=\frac{\bar{x}_{1}-\bar{x}_{2}}{\sqrt{\frac{s_{1}^{2}}{n_{1}}+\frac{s_{2}^{2}}{n_{2}}}}
$$


Poverty indices are,

$$
P_{\alpha}=\frac{1}{N} \sum_{i=1}^{q}\left(\frac{Z-Y_{i}}{Z}\right)^{\alpha}
$$

Where

$\mathrm{P}=$ Poverty index,

$\mathrm{N}=$ The size of the population under study,

$(\mathrm{Z}-\mathrm{Y})=$ the gap between the poverty line and the income of each poor individual,

$\mathrm{Z}=$ Poverty line

$\mathrm{q}=$ the number of individuals below the poverty line,

$\mathrm{Y}=$ per capita income of the household,

$\alpha=$ the parameter that takes the value $0,1,2$,

Po = Incidence of Poverty: this is the head count ratio or the prevalence of poverty. It indicates the proportions of the population below the poverty line. The higher the index, the greater the proportions of individuals or households that are poor.

$$
P O=\frac{n}{N}
$$

Poverty Depth/Gap/Intensity: that is a $=1$, the index becomes;

$$
P 1=\frac{1}{N} \sum\left(\frac{Z-Y}{Z}\right)
$$

It shows the average gap between the income of a poor individual or household and poverty line. The higher this index, the wider the poverty gap.

Severity of Poverty; this is when a $=2$, the index becomes;

$$
P 2=\frac{1}{N} \sum\left(\frac{Z-Y}{Z}\right)^{2}
$$

This means that the further away a person is from the poverty line, the higher the value of the index. Therefore, the higher the value of this index, the more severe the poverty.

\section{Farm Size}

\section{Result and Discussion}

Frequency distribution of respondents according to their farm size is presented in table 1 Majority (267) of the respondent non beneficiaries (89\%) cultivated farm sizes of between 0.1 to 2 hectares which represent the small scale farms. 32 non beneficiary respondents $(10.67 \%)$ had farm sizes of between 2.01 to 5 hectares which could be regarded as medium scale farms and only 1 non beneficiary respondent $(0.33 \%)$ had a farm size of above 5 hectares which can be termed large scale farm by Nigerian standard (see table 1). Also, 254 beneficiary respondents $(84 \%)$ cultivated farm sizes of between 0.1 to 2 hectares, 45 beneficiary respondents $(15 \%)$ had farm sizes of between 2.01 to 5 hectares and only 1 beneficiary respondent $(0.33 \%)$ had farm size of above 5 hectares.

The above analysis reveals that the majority of farmers were operating on small scale levels. The small and scattered nature of farms in the study area were partly due to the land tenure system which discriminated against large holdings by individuals and partly due the nature of farmers who cannot purchase any land from the paltry sum from the micro credit organization.

\section{Output of Maize}

Evaluation of any credit programme have been done on the basis of output produced and income earned based on these output. Hence this evaluation is based on the output of maize, cassava and yam.

Table 2 shows the distribution of respondents according to their output of maize. The table reveals that of the beneficiaries, 48 respondents (16\%) had output of between $0.5 \mathrm{~kg}$ and $100 \mathrm{~kg}, 184$ respondents $(61.33 \%)$ had between $100.5 \mathrm{~kg}$ and $200 \mathrm{~kg}, 61$ respondents $(22.33 \%)$ had output of between $200.5 \mathrm{~kg}$ and $300 \mathrm{~kg}$ and 1 respondent $(0.33 \%)$ had between $300.5 \mathrm{~kg}$ and $400 \mathrm{~kg}$ of maize. In the case of non beneficiaries, 269 respondents $(89.67 \%)$ had output of between $0.5 \mathrm{~kg}$ and $100 \mathrm{~kg}$ and 31 respondents $(10.33 \%)$ had output of between $100.5 \mathrm{~kg}$ and $200 \mathrm{~kg}$ of maize. Further analysis revealed that beneficiaries had an average output of $158 \mathrm{~kg}$ while non beneficiaries had an average output of $62 \mathrm{~kg}$ of maize. The test of the difference between means revealed that there was significant difference between the output of maize of beneficiaries and non beneficiaries. This implies that micro credit had significant influence on the yield of maize of beneficiaries. Such significant influence can be attributed to the fact that these beneficiaries had access to credit; this would have empowered them to use fertilizers, hired more labour and even purchased improved seeds which may have accounted for the higher output. 


\section{Cassava Output}

Table 3 show the distribution of respondents by output of cassava. The table shows that in the case of beneficiaries, 32 respondents $(10.67 \%$ ) had output levels of between $0.5 \mathrm{~kg}$ to $40 \mathrm{~kg}$ of tubers, 206 respondents $(68.66 \%)$ had output of between $40.5 \mathrm{~kg}$ and $80 \mathrm{~kg}$ of tubers and 62 respondents $(20.67 \%)$ had output of between $80.5 \mathrm{~kg}$ and $120 \mathrm{~kg}$ of tubers of cassava. In the case of non beneficiaries, 278 respondents $(92.67 \%$ had output of between $0.5 \mathrm{~kg}$ and $40 \mathrm{~kg}$ of tubers and 22 respondents $(7.33 \%)$ had output of between $40.5 \mathrm{~kg}$ and $80 \mathrm{~kg}$ of tubers of cassava. From the analysis, it was observed that the beneficiaries had an average cassava output of $64 \mathrm{~kg}$ of tubers while that of non beneficiaries was $23 \mathrm{~kg}$ of tubers of cassava. The test of difference in means of output of beneficiaries and non beneficiaries revealed that there is significant difference in the output of cassava. This means micro credit had significantly influenced the yield of cassava output of beneficiaries.

\section{Yam Output}

Table 4 shows the distribution of respondents by yam yield. The table shows that in the case of beneficiaries, 28 respondents $(9.33 \%)$ had output of between $0.67 \mathrm{~kg}$ and $67 \mathrm{~kg}$ of tubers, 173 respondents $(57.67 \%)$ had output of between $67.5 \mathrm{~kg}$ and $134 \mathrm{~kg}$ of tubers, 90 respondents $(30 \%)$ had output of between $134.5 \mathrm{~kg}$ and $201 \mathrm{~kg}$ of tubers and 9 respondents $(3 \%)$ had output of between $201.5 \mathrm{~kg}$ and $288 \mathrm{~kg}$ of tubers of yam. In the case of non beneficiaries, 238 respondents $(79.33 \%)$ had output of between $0.67 \mathrm{~kg}$ and $67 \mathrm{~kg}$ of tubers and 62 respondents $(20.67 \%)$ had output of between $67.5 \mathrm{~kg}$ and $134 \mathrm{~kg}$ of tubers of yam. Further analysis revealed that the beneficiaries had an average yam yield of $119 \mathrm{~kg}$ of tubers while the non beneficiaries had an average yield of $48 \mathrm{~kg}$ of yam tubers. The test of difference in means revealed that there was a significant difference in yam yield of the beneficiaries and that of non beneficiaries. This implies that the beneficiaries had higher yam yield than the non beneficiaries which could be attributable to micro credit.

\section{Incidence of Poverty (Po)}

\section{Poverty Status of Respondents}

Given the average per capita income of all respondents to be two thousand, nine hundred and eighty two Naira, fourteen kobo only (N2,982.14), the absolute poverty line was set at one thousand, nine hundred and eighty nine Naira, Nine kobo only (N1, 989.09), that is, two thirds of the mean income of all respondents. Based on this absolute poverty line, $21 \%$ of the beneficiaries and $43 \%$ of non beneficiaries were classified as being poor, while $79 \%$ of beneficiaries and $57 \%$ of non beneficiaries were categorized as non poor (see table 5).

Of the poor beneficiaries, $20 \%$ of them were categorized as core poor and $1 \%$ as hard core poor. In case of the non beneficiaries, $40 \%$ were classified as core poor and 3\% as hard core poor. From the above, incidence of poverty was higher with the non beneficiaries than with the beneficiaries. It can be inferred from the above that micro credit has reduced the incidence of poverty among beneficiaries and also, that micro credit can be used as a tool for poverty alleviation. This is in line with many authors who believed that micro credit can help to substantially reduce poverty (Coker, 2003; Littlefield, Morduch and Hashemi, 2003; Dunford, 2006).

Intensity of Poverty (P1): The intensity of poverty measures the gap between the poor household and the poverty line (Afonja and Ogwumike, 2003). The intensity of poverty among non beneficiaries (0.111) was higher than that of beneficiaries $(0.041)$ in the above table. The implication of this is that the gap between the poor non beneficiaries and the poverty line was $11.11 \%$ apart while the gap between the poor beneficiaries and the poverty line was $4 \%$ apart. The meaning of this is that the poor non beneficiaries would require two hundred and twenty four Naira, nine kobo (N224.09) and the poor beneficiaries would require eighty four Naira fifty five kobo (N84.55) every month to be able move above the poverty line. The depth of poverty between the beneficiary and non beneficiaries was statistically significant.

Severity of Poverty (P2): This measures the extent of poverty in an area. Poverty was more severe among the poor non beneficiaries with a poverty index of (0.029) than the poor beneficiaries with an index of (0.008). It indicated that the distribution of the poor below the poverty line was more uneven with non beneficiaries than with beneficiaries.

\section{Conclusion}

This study has examined the effect of micro credit on poverty alleviation among rural crop farmers, using empirical evidence from Edo State. It has been observed that micro credit has assisted in the increase of farm size and the output of maize, cassava and yam of beneficiaries. Micro credit has also played a crucial role in alleviating poverty of beneficiaries and thus enhancing their economic status. The effects will be more meaningful if the amount advanced as micro credit is increased from fifty thousand Naira only (N50, 000.00) to about two hundred thousand Naira only (N200, 000.00) 
Table 1: Farm Size of the Respondents

\begin{tabular}{|lccccccc|}
\hline \multicolumn{3}{|c|}{ Beneficiary } & \multicolumn{5}{c|}{ Total } \\
\hline Size & Frequency & Percentage & Frequency & Percentage & Frequency & Percentage \\
$\mathrm{Ha}$ & 267 & 89.00 & 254 & 84.67 & 521 & 86.83 & \\
$\mathrm{Ha}$ & 32 & 10.67 & 45 & 15.00 & 77 & 12.83 & \\
$5 \mathrm{Ha}$ & 1 & 0.33 & 1 & 0.33 & 2 & 0.34 & \\
\hline \multicolumn{2}{|c|}{300} & 100 & 300 & 100 & 600 & 100 \\
\hline
\end{tabular}

Source: Computed from Survey Data 2012

Table 2: Distribution of Respondents by output of Maize

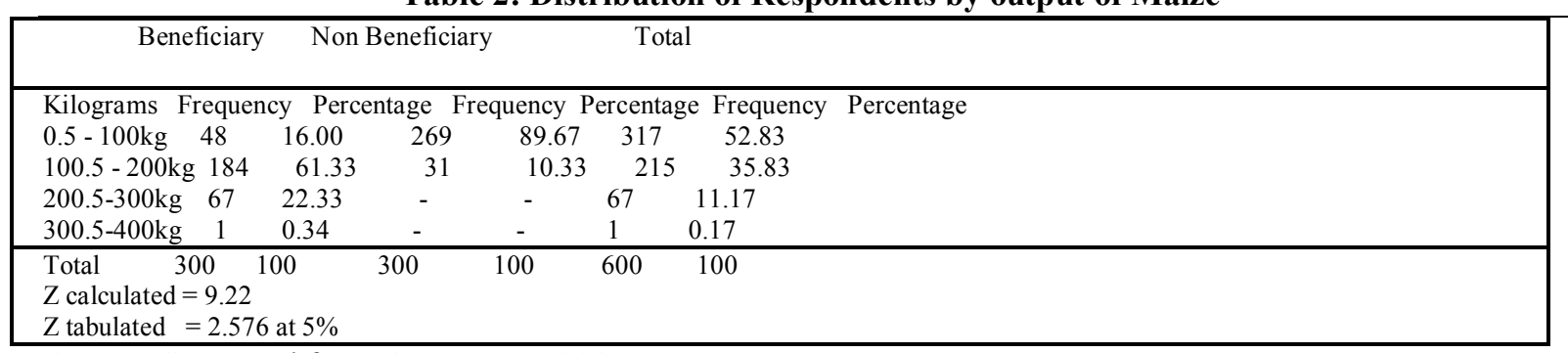

Source: Computed from Survey Data 2012

Table 3: Respondents by Cassava Output

\begin{tabular}{|llcccccc|}
\hline \multicolumn{10}{|c|}{ Non Beneficiary } & \multicolumn{3}{c|}{ Total } \\
\hline Kilograms & Frequency Percentage & Frequency & Percentage & Frequency & Percentage \\
$0.5-40 \mathrm{~kg}$ & 32 & 10.67 & 278 & 92.67 & 310 & 51.67 & \\
$40.5-80 \mathrm{~kg}$ & 206 & 68.67 & 22 & 7.33 & 228 & 38.00 & \\
$80.5-120 \mathrm{~kg}$ & 62 & 20.66 & - & - & 62 & 10.33 & \\
\hline Total 300 & 100 & 300 & 100 & 600 & 100 & \\
Z calculated $=9.80$ & & & & & \\
Z tabulated $=2.576$ at 5\% & & & & & \\
\hline
\end{tabular}

Source: Computed from Survey Data 2012

Table 4: Respondents by Yam Output

\begin{tabular}{|lccccccc|}
\hline \multicolumn{10}{|c|}{ Non Beneficiary } & Total \\
\hline Kilogram & Frequency & Percentage & Frequency & Percentage & Frequency & Percentage \\
$0,67-67 \mathrm{~kg}$ & 28 & 9.33 & 238 & 79.33 & 266 & 44.33 & \\
$67.5-134 \mathrm{~kg}$ & 173 & 57.67 & 62 & 20.67 & 235 & 39.17 & \\
$134.5-201 \mathrm{~kg}$ & 90 & 30.00 & - & - & 90 & 15.00 & \\
$201.5-288 \mathrm{~kg}$ & 9 & 3.00 & - & - & 9 & 1.50 & \\
\hline Total & 300 & 100 & 300 & 100 & 600 & 100 & \\
Z calculated $=8.89$ & & & & & \\
Z tabulated $=2.576$ at $5 \%$ & & & & & \\
\hline
\end{tabular}

Source: Computed from Survey Data 2012

Table 5: Incidence, Intensity and Severity of Poverty

\begin{tabular}{|ccccc|}
\hline Indices & Beneficiary & Non Beneficiary & Feal. & Ftab. \\
\hline $\begin{array}{c}\text { Incidence } \\
\text { of Poverty } \\
\text { (P0) }\end{array}$ & 0.210 & 0.430 & 2.05 & 1.00 \\
$\begin{array}{c}\text { Intensity of } \\
\text { Poverty } \\
\text { (P1) }\end{array}$ & 0.041 & 0.111 & 2.71 & 1.00 \\
$\begin{array}{c}\text { Severity of } \\
\text { Poverty } \\
\text { (P2) }\end{array}$ & 0.008 & 0.029 & 3.63 & 1.00 \\
\hline
\end{tabular}

Source: Computed from Survey Data, 2012 


\section{References}

[1]. Afonja, B. and F. O. Ogwumike (2003) 'Poverty: Meaning, Measurement and Causes' in M. I. Obadan, A. A. Fajingbesi and E. O. Oga (eds) Integrated Poverty Alleviation Strategies into Plans and Programmes in Nigeria. Ibadan: Secreprints Nig Ltd.

[2]. Chemin, M. (2008) 'The Benefit and Costs of Microfinance' Journal of Development 44(4) Pp463 - 483

[3]. Coker, J. B. (2003) 'Monitoring and Evaluation of Poverty in Nigeria' in M. I. Obadan, A. A. Fajingbesi and E. O. Uga (eds) Integrated Poverty Alleviation Strategies into Plans and Programmes in Nigeria. Ibadan: Secreprints Nig. Ltd.

[4]. Coleman, B. E. (1999) 'The Impact of Group Lending in Northeast Thailand' Journal of Development Economics. Vol. 60 Pp105 141

[5]. Dunford, C. (2006) Evidence of Microfinance Contribution to Achieving the Millenium Development Goals (MDG) Davis CA

[6]. Foster, A., J. Greer and Thorberke (1984) 'A Class of Decomposable Poverty Measures' Econometrica. Vol. 52

[7]. Hossain, F. and T. Knight. (2008) 'Can Microcredit Improve the Livelihood of the Poor and Disadvantaged?' International Development Planning Review 30(2) Pp155 - 175

[8]. Ilavbarhe, K. O. (2007) 'An Assessment of Sources and Utilisation of Credit by Small Scale Farmers in Benin Metropolis of Edo State, Nigeria' Global Journal of Agricultural Sciences 6(2) Pp $153-157$

[9]. Imoudu, P. B. (1998) 'A Review of Microcredit Structure and Administration in Ondo State, Nigeria' A Paper Presented at a Workshop on Microcredit as an Economic Empowerment for NGOs and SMEs Sponsored by UNDP and Ministry of Commerce and Industry, Akure, Ondo State May 28, 1998

[10]. Imoudu, P. B. (1999) 'Poverty Alleviation and Sustainable Income in Rural Communities: A perspectives Analysis' in Y. L. Fabiyi and E. O. Idowu (eds) Poverty Alleviation and Food Security in Nigeria. Ibadan. Kayod Nig. Ltd. Pp22 - 27

[11]. Mamun, C. A., N. Hasan and A. Rana (2013) 'Microcredit and Poverty Alleviation: The Case of Bangladesh' World Journal of Social Sciences 3(1) Pp102- 108

[12]. Morduch, J., S. Heshemi and E. Littlefield (2003) 'Is Microfinance an Effective Strategy to Reach the Millenium Development Goals?' Washington DC. Consultative Group to Assist the Poor Focus Note 24

[13]. National Population Commission NPC (1994) 'Census '91': National Summary of Census Figures' National Population Commission (NPC) Abuja

[14]. Oyatoye, E. T. O. (1981) 'Financing Small Scale Farmers: A Change of Strategy' in Edordu (eds) Agricultural Credit and Finance in Nigeria: Problems and Prospects. A Proceedings of a Seminar Organised by Central Bank of Nigeria, 1981

[15]. Ravallion, M. (1992) 'Poverty Comparisons: A Guide to Concepts and Methods' LSMS Working Paper No. 88 Washington DC World Bank

[16]. Scully, N. D. (2004) 'Microcredit no Panacea for Poor Women' Sited the Development Gap Organisation http//www.developmentgap.org/micro.html

[17]. Uniamikogbo, S. O. (1999) 'Methodological Issues and Problems in Social Research' in Aghayere, V. O. and S. O. J. Ojo (eds) Research Methods in Social Sciences. Ibadan. Sterling Hordon Publishers Nig. Ltdd.

[18]. United Nations (2009) 'The Millenium Development Goals Report 2009' New York

[19]. World Bank Group (2010) PovcatNethttp//iresearch.worldbank.org/povcatNet/povudphc.html 